\title{
Variation in Chitosan and Salicylic Acid Efficacy Towards Soil-borne and Air-borne Fungi and their Suppressive Effect of Tomato Wilt Severity Hayfa Jabnoun-Khiareddine ${ }^{1 *}$, Riad SR El-Mohamedy ${ }^{2}$, Farid Abdel-Kareem², Rania Aydi Ben Abdallah ${ }^{1,3}$, Mouna Gueddes-Chahed ${ }^{1}$ and Mejda Daami-Remadi ${ }^{1}$
}

${ }^{1}$ UR13AGR09-Integrated Horticultural Production in The Tunisian Centre-East, Regional Center of Research on Horticulture and Organic Agriculture, University of Sousse, 4042, Chott-Mariem, Tunisia

2Plant Pathology Department, National Research Center, Dokki, Giza, Egypt

${ }^{3}$ National Agronomic Institute of Tunisia, 1082 Tunis Mahrajène, University of Carthage, Tunisia

\begin{abstract}
Two resistance inducers (RIs), chitosan and salicylic acid (SA), were assessed in vitro for their antifungal activity against ten tomato phytopathogenic fungi i.e. Fusarium oxysporum f. sp. lycopersici, F. oxysporum f. sp. radicislycopersici, F. solani, Verticillium dahliae, Rhizoctonia solani, Colletotrichum coccodes, Pythium aphanidermatum, Sclerotinia sclerotiorum, Botrytis cinerea, and Alternaria solani. The impact of these RIs, applied as soil drench, on Verticillium wilt, Fusarium wilt, and Fusarium Crown and Root Rot severity and on growth parameters of tomato cv. Rio Grande plants were also investigated. Chitosan $(0.5-4 \mathrm{mg} / \mathrm{ml})$ and SA $(1-25 \mathrm{mM})$ inhibited mycelial growth of all pathogens in Potato Dextrose Agar (PDA) medium in a concentration-dependent manner, with the greatest inhibition achieved using the highest chitosan and SA concentrations. Inter specific variations in sensitivity to chitosan and SA were detected. $P$. aphanidermatum and S. Sclerotiorum were the most sensitive to both Rls. Single treatments with chitosan $(4 \mathrm{mg} / \mathrm{ml})$ and SA $(10 \mathrm{mM})$ resulted in varied degree of protection against wilt diseases. Chitosan-and SA-based treatments resulted in $42.1-73.68,60.86-78.26$ and $45-50 \%$ reductions in wilt severity, as compared to VD-, FOL- and FORL-inoculated and untreated controls, respectively. All growth parameters noted were enhanced using RIs compared to pathogen-inoculated controls. In fact, SA-based treatment had significantly increased plant height, root and aerial part fresh weights by $17.94,52.17$ and $33.33 \%$, by $23.01,55.40$ and $29.72 \%$, and by 17.72 , 50 and $46.84 \%$, respectively, while compared to VD-, FOL- and FORL-inoculated and untreated plants. Chitosantreated plants showed increment in their height, root and aerial part fresh weights by $13.81,62.16$ and $38.97 \%$, respectively, compared to FORL-inoculated and untreated control. Results from this investigation showed that SA and chitosan may be used as potential inducers of systemic acquired resistance for successfully controlling fungal tomato diseases in Tunisia.
\end{abstract}

Keywords: Chitosan; Salicylic acid; Antifungal activity; Tomato pathogens; Wilt severity

\section{Introduction}

Tomato (Solanum lycopersicum L., formerly, Lycopersicon esculentum Mill.), is one of the most important vegetable crop worldwide after potato, regarding areas under cultivation and ranked second after eggplant in terms of production [1,2]. In Tunisia, tomato is regarded as one of the most important crops in terms of both value and cropped areas. In fact, average areas of $29000 \mathrm{ha} /$ year are devoted to the growing of open field and protected tomatoes covering about $17 \%$ of areas cultivated with vegetables, with an average annual production of about 1.2 million tons representing about $39 \%$ of national production of vegetable crops [3]. Tomato is grown both on small- and large-scales commercial crop. However, diseases are ones of the main problems of tomato cropping in Tunisia and all over the world leading to considerable production decrease [4-6].

In Tunisia, several fungal diseases are known to affect tomato during all stages of plant development resulting in severe damage in roots and/or crown, stems, leaves and fruits. Fusarium oxysporum f. sp. lycopersici (FOL), F. oxysporum f. sp. radicis-lycopersici (FORL) and Verticillium dahliae (VD) are highly destructive soil-borne pathogens causing wilt and root rot diseases in both greenhouse and field-grown tomatoes in warm producing areas. In fact, yield losses up to 50 and $90 \%$ due to Verticillium wilt and Fusarium Crown and Root Rot disease, respectively, have been reported on severely infected tomato cultivars [5,7]. Furthermore, F. solani, R. solani, C. coccodes, $P$. aphanidermatum, and S. sclerotiorum, causing root rots and stem decay, are among the most well-known soil-borne pathogenic fungi which are reportedly responsible for severe growth reduction and yield losses in Tunisia. In addition, grey mold caused by $B$. cinerea and early blight incited by $A$. solani are among the most important diseases of tomato aerial parts leading to lower quantity and quality of fruit yields $[8,9]$.

Many strategies have been developed for controlling tomato fungal diseases over years such as cultural practices, chemical treatments, use of resistant cultivars, grafting, soil solarisation, biological control, etc., but serious losses still occur largely because the effectiveness of these approaches is variable and often short lived [5,7]. In fact, the exceptionally long survival of resting structures of soilborne pathogens (chlamydospores, oospores, sclerotia, microsclerotia, etc) along with

*Corresponding author: Hayfa Jabnoun-Khiareddine, UR13AGR09-Integrated Horticultural Production in the Tunisian Centre-East, Regional Center of Research on Horticulture and Organic Agriculture, University of Sousse, 4042, Chott-Mariem, Tunisia, E-mail: jkhayfa@yahoo.fr

Received December 20, 2015; Accepted December 29, 2015; Published December 31, 2016

Citation: Jabnoun-Khiareddine H, El-Mohamedy RSR, Abdel-Kareem F, Aydi Ben Abdallah R, Gueddes-Chahed M, et al. (2015) Variation in Chitosan and Salicylic Acid Efficacy Towards Soil-borne and Air-borne Fungi and their Suppressive Effect of Tomato Wilt Severity. J Plant Pathol Microbiol 6: 325. doi:10.4172/21577471.1000325

Copyright: (c) 2015 Jabnoun-Khiareddine H, et al. This is an open-access article distributed under the terms of the Creative Commons Attribution License, which permits unrestricted use, distribution, and reproduction in any medium, provided the original author and source are credited. 
Citation: Jabnoun-Khiareddine H, El-Mohamedy RSR, Abdel-Kareem F, Aydi Ben Abdallah R, Gueddes-Chahed M, et al. (2015) Variation in Chitosan and Salicylic Acid Efficacy Towards Soil-borne and Air-borne Fungi and their Suppressive Effect of Tomato Wilt Severity. J Plant Pathol Microbiol 6: 325. doi:10.4172/2157-7471.1000325

the continuous cropping of susceptible tomato cultivars and the emergence of new races and pathotypes of pathogens make difficult the control of these diseases and lead to an intense use of agrochemicals. In fact, tomatoes are one of the highest pesticide-sprayed vegetables worldwide. Hence, the excessive use of synthetic fungicides has resulted in an increased risk of fungicide resistance, enhanced pathogen resurgence and development of resistance/cross-resistance, toxicological implications to human and animal health, and increased environment pollution $[10,11]$.

Therefore, recent efforts have focused on developing environmentally safe, long lasting and effective alternative methods for the management of these tomato diseases, such as the use of resistance inducers (RIs). In fact, in addition to basal resistance, plants are capable of developing an induced resistance that is a physiological state of acquired defensive capacity elicited by specific environmental stimuli, by which plants' innate defences, are potentiated against subsequent biotic challenge [10-12]. Chemical inducers of plant resistance possess quite different modes of action as compared to synthetic biocides as they have no direct toxicity to pathogens, plants and animals; no negative effects on plant growth, development and yield; broad spectrum of defence; low loading amount; long lasting protection; low economical cost for farmers and good profit for producers [13-15]. A large array of natural and chemical RIs have been reported to induce resistance in many plants including tomato such as benzothiadiazole, betaaminobutyric acid (BABA), 2,6-dichloroisonicotinic acid, salicylic acid (SA), organic and inorganic salts, chitosan and chitin, etc [13,14,16-19].

Among natural elicitor compounds, chitosan offers a great potential as a biodegradable substance that has both anti-microbial and eliciting activities [20]. Its fungicidal potential has been reported against various species of fungi and oomycetes involved in many pre- and post-harvest diseases of horticultural commodities [21,22].

Among the most commonly tested chemical elicitors, salicylic acid has been shown to play an important role in expression of both local resistance, controlled by major genes, and systemic induced resistance developed after an initial pathogen attack [23]. In fact, SA has been used successfully to control several plant diseases such as Fusarium wilt and crown and root rot of tomato [24-26], tomato root rots [27], root rot/wilt of sesame [28], Verticillium wilt of eggplant [29], Fusarium wilt of chickpea and asparagus [30,31].

Therefore, the objectives of the present work were to (i) evaluate the in vitro antifungal activity of chitosan and SA against ten tomato pathogens causing wilts, root rots, stem decay and fruit rots, (ii) to assess their suppressive effects of Verticillium and Fusarium wilts and (iii) to elucidate their impacts on tomato growth, under growth chamber conditions.

\section{Materials and Methods}

\section{Plant material}

Tomato seeds (cv. Rio Grande) were superficially disinfected by immersion in absolute ethanol for $2 \mathrm{~min}$, followed by extensive rinsing in sterile distilled water. Seeds were sown in alveolus plates filled with previously sterilised peat. Seedlings were grown in a growth chamber at $24-26^{\circ} \mathrm{C}$ with $12-\mathrm{h}$ photoperiod and $70 \%$ humidity. They were watered daily and fertilized once a week with a standard nutrient solution according to [32]. Experiments were performed using 30 days-old tomato plants.

\section{Fungal species}

The fungal pathogens used in this study were: FOL, FORL, $F$. solani, VD, C. coccodes, $R$. solani, P. aphanidermatum, S. sclerotiorum, $B$. cinerea, and A. solani. These pathogens were isolated from roots, crowns, stems, leaves and fruits of diseased tomato plants and were held in the fungal culture collection of the laboratory of Phytopathology in the Regional Center of Horticulture and Organic Agriculture of Chott Mariem- Tunisia. Cultures of each fungus were maintained on Potato Dextrose Agar (PDA; Difco, Detroit, MI, USA) and were stored in PDA slants at $5^{\circ} \mathrm{C}$ for further use.

Liquid cultures used for substrate inoculation were prepared on Potato Dextrose Broth (PDB) and incubated at $25^{\circ} \mathrm{C}$ under continuous shaking at $150 \mathrm{rpm}$ during 4 to 5 days. Concentration of the conidial suspension used was adjusted to $10^{7}$ conidia/ml using a Malassez haemocytometer.

\section{Resistance inducers tested}

The RIs tested in this study are listed in Table 1.

To prepare chitosan (Sigma-Aldrich, St. Louis, MO, USA) stock solutions $(10 \mathrm{mg} / \mathrm{ml}), 2 \mathrm{~g}$ of high molecular weight chitosan (viscosity $=800-2000 \mathrm{cps}$ and $>75 \%$ deacetylation) were dissolved in 100 $\mathrm{ml}$ of distilled water with $2 \mathrm{ml}$ of acetic acid (stirred for $24 \mathrm{~h}$ ), and the volume was taken up to $200 \mathrm{ml}$ with distilled water. The $\mathrm{pH}$ was adjusted to 5.6 by the addition of sodium hydroxide $1.0 \mathrm{~N}$ [33]. Chitosan solution was autoclaved for $15 \mathrm{~min}$. The corresponding aliquots were taken to obtain different chitosan concentrations $(0.5,1.0,1.5,2.0,2.5,3.0$ and $4 \mathrm{mg} / \mathrm{ml}$ ).

SA was tested at concentrations of $1,5,10$ and $25 \mathrm{mM}$. The corresponding aliquots were taken from a $1 \mathrm{M}$ stock solution in sterile distilled water.

\section{In vitro antifungal activity of the resistance inducers against tomato pathogens}

The inhibitory effect of chitosan and salicylic acid on the mycelial growth of tomato pathogens was evaluated on PDA medium supplemented with streptomycin sulfate $(300 \mathrm{mg} / \mathrm{l})$.

The desired quantities of the tested inducers were added to autoclaved and molten PDA medium to achieve the targeted concentrations tested. For each compound, a $10 \mathrm{ml}$ aliquot of amended PDA medium was aseptically poured into a Petri plate $(9 \mathrm{~cm}$ in diameter), with an unamended PDA dish used as a control. Three agar plugs $(6 \mathrm{~mm}$ in diameter) cut from 7-day-old fungal cultures were plated at $2 \mathrm{~cm}$ from the edge of the Petri plate and equidistantly spaced from each other by $3 \mathrm{~cm}$. The plates were sealed with parafilm and incubated in the dark at $25^{\circ} \mathrm{C}$ for varying times depending on growth rate of each organism and time necessary for reaching the edge of the plate. This was as briefly as 1 day for fast-growing organisms like P. aphanidermatum and as long as 7 days for slower growing ones like VD. Colony diameters were measured at two perpendicular points and the mean was determined. The mycelial growth inhibition percentage was calculated according to Tiru et al. formula [34] as follows: I $\%=[(\mathrm{C} 2-\mathrm{C} 1) / \mathrm{C} 2] \times 100$ with $\mathrm{C} 2$ :

\begin{tabular}{|c|c|c|c|}
\hline Compound & Chemical formula & Molecular weight & Company \\
\hline Salicylic acid & $\mathrm{C}_{7} \mathrm{H}_{6} \mathrm{O}_{3}$ & $138.12(\mathrm{~g} / \mathrm{mol})$ & Merck (Darmstadt, Germany) \\
\hline Chitosan & $\mathrm{C}_{12} \mathrm{H}_{24} \mathrm{~N}_{2} \mathrm{O}_{9}$ & $\mathrm{Mw}=30.7 \mathrm{kDa}$ & Sigma-Aldrich (St. Louis, MO, USA) \\
\hline
\end{tabular}

Table 1: Resistance inducers tested in this study. 
Citation: Jabnoun-Khiareddine H, El-Mohamedy RSR, Abdel-Kareem F, Aydi Ben Abdallah R, Gueddes-Chahed M, et al. (2015) Variation in Chitosan and Salicylic Acid Efficacy Towards Soil-borne and Air-borne Fungi and their Suppressive Effect of Tomato Wilt Severity. J Plant Pathol Microbiol 6: 325. doi:10.4172/2157-7471.1000325

Mean diameter of the control colony and C1: Mean pathogen colony diameter in the presence of the tested compound. The experiment was repeated twice, with three replicates per treatment.

Statistical analyses were performed, for each RI, following a completely randomised factorial design where the pathogens and the inducer concentrations were the two fixed factors. Six replicates were used for each individual treatment and means were separated using Fisher's protected LSD or Duncan's Multiple Range tests (at $P \leq 0.05$ ). The whole experiment was repeated twice but only the data of one essay is presented in the present study. Statistical analyses were performed using SPSS software version 16.

\section{Effect of the resistance inducers on Verticillium and Fusarium wilts severity under growth chamber conditions}

Chitosan $(4 \mathrm{~g} / \mathrm{l})$ and salicylic acid $(10 \mathrm{mM})$ were tested in vivo, as soil drench, for controlling Verticillium wilt, Fusarium wilt and Fusarium crown and root rot.

Healthy 30 days-old tomato seedlings (cv. Rio Grande) were carefully removed from alveolus plates and re-potted in peat contained in $17 \mathrm{~cm}$ diameter-pot. Two days after transplanting, plants were watered by $100 \mathrm{ml}$ of each inducer aqueous solution, as close as possible to the root system. This quantity was sufficient to cover tomato roots without excess. Plants were watered only three days post-treatment, in order to allow a maximum root wetting in the RIs aqueous solution. Five days post-treatments, plants were challenged by $100 \mathrm{ml}$ of each fungal conidial suspension close to the root system.

For each individual treatment, five plants were used and the experiment was repeated twice. Five uninoculated and untreated plants and five inoculated and untreated others were used as controls.

All tomato plants were maintained in a growth chamber at $15-30^{\circ} \mathrm{C}$ during 60 days and regularly watered and fertilized with a standard nutrient solution according to [32].

Assessment of disease severity was performed 60 days post inoculation (DPI) of tomato plants challenged with pathogens (VD, FOL and FORL) using a disease index recorded on each plant according to wilt and leaf yellowing intensity and a mean value was calculated and considered as disease severity score. For evaluation of wilt symptom, each plant was observed and rated as follows: $0=$ no symptoms, $1=1-25 \%$ plant wilting and yellowing; $2=26-50 \%$ wilting and yellowing; $3=51-75 \%$ wilting and yellowing; $4=76-99 \%$ and $5=$ dead plant. Furthermore, Plant height and root and aerial part fresh weights were also noted for all tomato plants.

For all parameters measured (disease severity, plant height, root and aerial part fresh weight), statistical analyses were performed for each pathogen used (VD, FOL and FORL) following a completely randomised design where treatments (RIs, inoculated and untreated control and the uninoculated and untreated control) represented the only fixed factor. Five replicates were used per individual treatment and means were separated using Duncan's Multiple Range test (at $P \leq$ 0.05). Statistical analyses were performed using SPSS software version 16.

\section{Results}

\section{In vitro evaluation of the antifungal activity of resistance inducers against tomato pathogens}

The inhibitory effect of two RIs, chitosan and salicylic acid, tested at different concentrations on the mycelial growth of various tomato pathogenic fungi was assessed in vitro.

For each inducer, ANOVA analysis revealed a significant (at $P \leq$ 0.01 ) variation in the average fungal colony diameter depending on the tomato pathogens tested and RI concentrations used.

Data shown in Table 2 indicated that chitosan inhibited mycelial growth of all pathogens in solid PDA medium, in a concentrationdependent manner. It is clear that, linear growth of tested fungi decreased significantly with the increase of chitosan concentrations. In fact, as compared to the untreated control, chitosan had inhibited fungal mycelial growth (combined data of all fungi tested) at variable rates depending on concentrations uses where the inhibition ranged between 47.71 and $100 \%$ using chitosan at $4 \mathrm{mg} / \mathrm{ml}$ compared to $0-24.19 \%, 2.15-36.97 \%, 10.92-79.21 \%, 11.27-83.87 \%, 21.03-100 \%$, and $36.27-100 \%$ achieved using this RI at $0.5,1,1.5,2,2.5$ and $3 \mathrm{mg} / \mathrm{ml}$ respectively.

\begin{tabular}{|c|c|c|c|c|c|c|c|c|c|}
\hline \multirow[b]{2}{*}{ Fungi tested } & \multicolumn{9}{|c|}{ Chitosan concentration used (g/l) } \\
\hline & 0 & 0.5 & 1 & 1.5 & 2 & 2.5 & 3 & 4 & Average per fungus tested ${ }^{a *}$ \\
\hline FOL & 3.97 & 2.98 & 2.50 & 2.20 & 1.93 & 1.85 & 1.78 & 1.40 & $2.33 \mathrm{e}$ \\
\hline FORL & 4.05 & 3.75 & 3.22 & 2.07 & 1.92 & 1.65 & 1.55 & 1.52 & $2.46 \mathrm{~d}$ \\
\hline F. solani & 3.63 & 3.55 & 3.22 & 2.55 & 2.45 & 2.42 & 2.02 & 1.90 & $2.72 \mathrm{c}$ \\
\hline VD & 3.32 & 3.13 & 2.62 & 2.00 & 1.83 & 1.60 & 1.42 & 1.20 & $2.14 \mathrm{f}$ \\
\hline C. coccodes & 3.57 & 3.47 & 3.00 & 2.98 & 2.97 & 2.82 & 2.02 & 1.50 & $2.79 \mathrm{c}$ \\
\hline R. solani & 4.73 & 4.48 & 4.38 & 4.22 & 4.20 & 3.62 & 3.02 & 2.15 & $3.85 \mathrm{a}$ \\
\hline S. sclerotiorum & 4.65 & 4.65 & 4.55 & 0.97 & 0.75 & 0.35 & 0 & 0 & $1.99 \mathrm{f}$ \\
\hline P. aphanidermatum & 4.48 & 4.42 & 3.50 & 2.30 & 1.30 & 0 & 0 & 0 & $2.00 \mathrm{f}$ \\
\hline B. cinerea & 4.72 & 3.83 & 3.70 & 3.18 & 2.87 & 2.23 & 2.10 & 1.05 & $2.96 \mathrm{~b}$ \\
\hline A. solani & 4.03 & 3.68 & 3.15 & 1.68 & 1.30 & 1.25 & 1.12 & 0.98 & $2.15 \mathrm{f}$ \\
\hline $\begin{array}{l}\text { Average per Chitosan } \\
\text { concentration }^{\mathrm{b}^{*}}\end{array}$ & $4.12 \mathrm{a}$ & $3.80 \mathrm{~b}$ & $3.38 \mathrm{c}$ & $2.42 \mathrm{~d}$ & $2.15 \mathrm{e}$ & $1.78 \mathrm{f}$ & $1.50 \mathrm{~g}$ & $1.17 \mathrm{~h}$ & \\
\hline
\end{tabular}

LSD (Fungal pathogens $x$ Chitosan concentrations) $=0.388 \mathrm{~cm}$ at $P \leq 0.05$

aean mycelial growth per fungal pathogen for all chitosan concentrations combined.

Mean mycelial growth per chitosan concentration tested for all fungal pathogens combined.

* For fungal pathogens and chitosan concentrations tested, values (means) followed by the same letter are not significantly different according to Duncan's Multiplue Range test at $P \leq 0.05$

Pathogens were cultured on PDA medium and incubated at $25^{\circ} \mathrm{C}$ for $1 \mathrm{~d}(P$. aphanidermatum), $2 \mathrm{~d}(R$. solani and $S$. sclerotiorum), $3 \mathrm{~d}(B$. cinerea, FOL, FORL and $F$. solani), $4 \mathrm{~d}$ (A. solani and C. coccodes) and $7 \mathrm{~d}$ (VD).

Table 2: Effect of different chitosan concentrations on the in vitro mycelial growth of tomato fungal pathogens cultured on PDA medium at $25^{\circ} \mathrm{C}$ 
Citation: Jabnoun-Khiareddine H, El-Mohamedy RSR, Abdel-Kareem F, Aydi Ben Abdallah R, Gueddes-Chahed M, et al. (2015) Variation in Chitosan and Salicylic Acid Efficacy Towards Soil-borne and Air-borne Fungi and their Suppressive Effect of Tomato Wilt Severity. J Plant Pathol Microbiol 6: 325. doi:10.4172/2157-7471.1000325

Tomato pathogens showed clear differences when grown in chitosan-amended PDA at different concentrations. In fact, increasing chitosan concentration from 0.5 to $4 \mathrm{mg} / \mathrm{ml}$ resulted in greater inhibition of mycelial growth of FOL, FORL and $F$. solani from 24.79 to $64.71 \%$, from 7.41 to $62.55 \%$, and from 2.29 to $47.71 \%$, respectively. For the two airborne pathogens, $B$. cinerea and A. solani, these inhibition rates ranged between $18.73-77.74 \%$ and $8.68-75.62 \%$, respectively. Decreases in mycelial growth of $R$. solani, C. coccodes and VD varied from $5.28-54.58 \%, 2.80-57.94 \%$ and $5.53-63.82 \%$, respectively, when treated with chitosan at 0.5 to $4 \mathrm{mg} / \mathrm{ml}$, compared to $0-100 \%$ and 1.49 $100 \%$ noted respectively for S. sclerotiorum and P. aphanidermatum. Thus, P. aphanidermatum and S. sclerotiorum were the most sensitive fungal species to chitosan as their growth was totally suppressed at concentrations of $2.5 \mathrm{mg} / \mathrm{ml}$ and $3 \mathrm{mg} / \mathrm{ml}$ or greater, respectively while when tested at $0.5 \mathrm{mg} / \mathrm{ml}$, chitosan did not affect S. sclerotiorum growth but only a slight inhibitory activity was observed at $1 \mathrm{mg} / \mathrm{ml}$. In contrast, $F$. solani was the least sensitive to chitosan where $47.71 \%$ decrease in pathogen growth was achieved with the highest chitosan concentration tested $(4 \mathrm{mg} / \mathrm{ml})$.

Applied at $2 \mathrm{mg} / \mathrm{ml}$, chitosan reduced by more than $50 \%$ the mycelial growth of five fungi out of the ten tested while at $4 \mathrm{mg} / \mathrm{ml}$, inhibition rates ranged between 50 and $65 \%$ for R. solani, C. coccodes, FORL, VD, and FOL and between 75 and $100 \%$ for A. solani, B. cinerea, P. aphanidermatum and S. sclerotiorum.

Results shown in Table 3 indicated that SA inhibited mycelial growth of all pathogens grown in amended-PDA medium, in a concentrationdependent manner. In fact, as compared to the untreated control, this RI decreased pathogens' growth by $2.41-31.2 \%$ at $1 \mathrm{mM}$ compared to $9.69-100 \%$ and $35.45-100 \%$, recorded at 5 and $10 \mathrm{mM}$, respectively. However, when tested at $25 \mathrm{mM}$, SA had totally suppressed in vitro growth of all tested pathogens.

Moreover, when SA concentration increased from 1 to $10 \mathrm{mM}$, inhibition of radial growth of FOL, FORL and F. solani augmented from 19.03 to $35.45 \%$, from 23 to $53.31 \%$ and from 31.27 to $49.48 \%$, respectively, compared to $2.14-100 \%, 6.20-100 \%$ and $7.11-100 \%$ noted on R. solani, C. coccodes and VD cultures, respectively. When treated with these increasing SA concentrations, mycelial growth of $B$. cinerea and $A$. solani was also reduced by $1.79-48.93 \%$ and $20.93-63.57 \%$, respectively, compared to inhibitions of $15-100 \%$ and $21.21-100 \%$ noted for S. sclerotiorum and P. aphanidermatum, respectively. In fact, these two last pathogens were the most sensitive fungal species to SA as their radial growth was completely suppressed at $5 \mathrm{mM}$ and greater followed by R. solani, C. coccodes and VD for which total inhibition was achieved using SA at $10 \mathrm{mM}$ and more.

Applied at $10 \mathrm{mM}$, SA had suppressed totally the growth of five out of the ten fungi tested (S. sclerotiorum, P. aphanidermatum, R. solani, $C$. coccodes and VD) and reduced by $35.45-63.57 \%$ the remaining pathogens (FOL, FORL and F. solani, B. cinerea, and A. solani).

SA used at $1 \mathrm{mM}$ led to great variation in terms of mycelial growth inhibition ability depending on fungi tested. In fact, the greatest inhibitory effect was recorded against $F$. solani $(31.27 \%)$ followed by FORL (23\%), P. aphanidermatum (21.21\%), A. solani (20.93\%), FOL (19.03\%), S. sclerotiorum (15.77\%), VD (7.11\%), C. coccodes (6.20\%), R. solani $(2.14 \%)$, and B. cinerea (1.79\%).

\section{Effect of the resistance inducers on wilt severity and plant growth}

The in vivo effect of chitosan and SA applied as soil drench, 5 days before single inoculation with three soil-borne fungi (VD, FOL and FORL) was evaluated on wilt severity and plant growth in comparison to untreated and inoculated or non-controls.

\section{Wilt severity}

All pathogen-inoculated tomato plants showed 60 DPI typical wilt symptoms while uninoculated and untreated plants were symptomless. However, for each pathogen, wilt severity varied significantly (at $P \leq$ 0.05 ) depending on treatments tested (Table 4). In fact, Verticillium wilt severity noted on SA- and chitosan-treated plants was significantly reduced by 42.1 and $73.68 \%$, respectively, compared to VD-inoculated and untreated control ones. Application of chitosan, as soil drench, provided $31.57 \%$ greater protection against Verticillium wilt severity than SA-based treatment.

Varied degree of protection of tomato plants against Fusarium wilt was recorded with RIs tested. In fact, SA- and chitosan-based treatments led to 78.26 and $60.86 \%$ lower disease severity, as compared to FOL-inoculated and untreated control. Exogenously supplied SA

\begin{tabular}{|c|c|c|c|c|c|c|}
\hline & \multicolumn{5}{|c|}{ Salicylic acid concentration used (mM) } \\
\hline Fungi tested & $\mathbf{0}$ & $\mathbf{1}$ & $\mathbf{5}$ & $\mathbf{1 0}$ & $\mathbf{2 5}$ & $\begin{array}{c}\text { Average per } \\
\text { fungus tested }\end{array}$ \\
\hline FOL & 4.47 & 3.62 & 2.95 & 2.88 & 0 & $2.78 \mathrm{ab}$ \\
\hline FORL & 4.78 & 3.68 & 3.13 & 2.23 & 0 & $2.77 \mathrm{ab}$ \\
\hline F. solani & 4.85 & 3.33 & 3.05 & 2.45 & 0 & $2.74 \mathrm{ab}$ \\
\hline VD & 3.28 & 3.05 & 2.68 & 0 & 0 & $1.80 \mathrm{~d}$ \\
\hline C. coccodes & 4.30 & 4.03 & 3.88 & 0 & 0 & $2.44 \mathrm{bc}$ \\
\hline R. solani & 4.82 & 4.72 & 3.63 & 0 & 0 & $2.63 \mathrm{abc}$ \\
\hline S. sclerotiorum & 4.97 & 4.18 & 0 & 0 & 0 & $1.83 \mathrm{~d}$ \\
\hline P. aphanidermatum & 4.40 & 3.47 & 0 & 0 & 0 & $1.57 \mathrm{~d}$ \\
\hline $\begin{array}{c}\text { B. cinerea } \\
\text { A. solani }\end{array}$ & 4.67 & 4.58 & 3.03 & 2.38 & 0 & $2.93 \mathrm{a}$ \\
\hline $\begin{array}{c}\text { Average per } \\
\text { salicylic acid } \\
\text { concentration }\end{array}$ & 4.30 & 3.40 & 2.40 & 1.57 & 0 & $2.33 \mathrm{C}$ \\
\hline
\end{tabular}

LSD (Fungal pathogens $\times$ SA concentrations) $=0.631 \mathrm{~cm}$ at $P \leq 0.05$.

a Mean mycelial growth per fungal pathogen for all salicylic acid concentrations combined.

${ }^{b}$ Mean mycelial growth per salicylic acid concentration for all fungal pathogens combined.

*For fungal pathogens and salicylic acid concentrations tested, values (means) followed by the same letter are not significantly different according to Duncan's Multiple Range test at $P \leq 0.05$.

Pathogens were cultured on PDA medium and incubated at $25^{\circ} \mathrm{C}$ for $1 \mathrm{~d}(P$. aphanidermatum), $2 \mathrm{~d}(R$. solani and $S$. sclerotiorum), $3 \mathrm{~d}$ (B. cinerea, FOL, FORL and $F$. solani), $4 \mathrm{~d}$ (A. solani and $C$. coccodes) and $7 \mathrm{~d}$ (VD).

Table 3: Effect of different salicylic acid concentrations on the in vitro mycelia growth of tomato fungal pathogens cultured on PDA medium at $25^{\circ} \mathrm{C}$

\begin{tabular}{|c|c|c|c|}
\hline \multirow{2}{*}{ Treatment/Pathogen } & \multicolumn{3}{|c|}{ Disease severity } \\
\cline { 2 - 4 } & VD & FOL & FORL \\
\hline Salicylic acid & $2.2 \mathrm{~b}$ & $1 \mathrm{c}$ & $2 \mathrm{~b}$ \\
\hline Chitosan & $1 \mathrm{c}$ & $1.8 \mathrm{~b}$ & $2.2 \mathrm{~b}$ \\
\hline Inoculated control & $3.8 \mathrm{a}$ & $4.6 \mathrm{a}$ & $4 \mathrm{a}$ \\
\hline Uninoculated control & $0 \mathrm{~d}$ & $0 \mathrm{~d}$ & $0 \mathrm{c}$ \\
\hline
\end{tabular}

*For each pathogen tested, values (means) followed by the same letter are not significantly different according to Duncan's Multiple Range test at $P \leq 0.05$.

Table 4: Effect of chitosan- and salicylic acid-based treatments on disease severity noted on tomato cv. Rio Grande plants inoculated with Verticillium dahliae (VD), Fusarium oxysporum f. sp. lycopersici (FOL) and F. oxysporum f. sp. radicislycopersici (FORL) noted 60 days post-inoculation under growth chamber conditions. Chitosan $(4 \mathrm{mg} / \mathrm{ml})$ and SA $(10 \mathrm{mM})$ were applied as soil drench five days before inoculation. Wilt severity was assessed based on $0-5$ scale (where $0=$ no symptoms and $5=$ dead plant) 
Citation: Jabnoun-Khiareddine H, El-Mohamedy RSR, Abdel-Kareem F, Aydi Ben Abdallah R, Gueddes-Chahed M, et al. (2015) Variation in Chitosan and Salicylic Acid Efficacy Towards Soil-borne and Air-borne Fungi and their Suppressive Effect of Tomato Wilt Severity. J Plant Pathol Microbiol 6: 325. doi:10.4172/2157-7471.1000325

improved protection against Fusarium wilt by $17.39 \%$ compared to chitosan based-treatment.

SA and chitosan applied through soil drench had statistically equivalent capacity to reduce Fusarium Crown and Root Rot severity by 50 and $45 \%$, respectively, compared to FORL-inoculated and untreated control.

\section{Plant height}

Plant height noted 60 DPI on tomato plants varied significantly (at $P \leq 0.05)$ depending on treatments tested. In fact, as given in Table 5 , SA treatment had significantly increased plant height by $17.94 \%$ compared to VD-inoculated plants and was statistically comparable to the untreated and uninoculated control. Chitosan-treated plants showed significantly comparable height to that noted on both untreated controls (inoculated or non) and also on SA-treated plants.

SA-treated plants showed a slight increase of about 5.12\%, even statistically insignificant, of their height in comparison to the untreated and uninoculated control.

SA-treated plants showed significant increase by 23.01 and $20.18 \%$ in their height compared to FOL-inoculated and non-controls, respectively. However, chitosan-treated plants showed statistically comparable height than that noted on both untreated controls and on SA-treated plants. In fact, slight height increases of about 18.4 and $15.4 \%$, even statistically insignificant, were noted on chitosan-treated plants in comparison to uninoculated or non-controls.

SA- and chitosan-treated plants showed significantly improved height of about 17.72 and $13.81 \%$, respectively, compared to FORLinoculated and untreated control and which were significantly similar to the uninoculated control. Plants inoculated with FORL showed significantly decreased height of about $9.95 \%$ compared to uninoculated control.

\section{Root fresh weight}

Root fresh weight noted 60 DPI on tomato plants varied significantly (at $P \leq 0.05$ ) depending on treatments tested. Indeed, data given in Table 6 showed that SA treatment had significantly increased root fresh weight by $52.17 \%$ compared to VD-inoculated plants and induced a slight increase of root weight of about $23.91 \%$, even statistically insignificant, when compared to the untreated and uninoculated control.

Chitosan-treated plants showed significantly comparable root fresh weight to that noted on both untreated controls (VD-inoculated or non) and also on SA-treated plants. An increase of about $42.10 \%$ in root fresh weight, even statistically insignificant, was noted on chitosantreated plants in comparison to the untreated and uninoculated control.

\begin{tabular}{|c|c|c|c|}
\hline \multirow{2}{*}{ Treatment/Pathogen } & \multicolumn{3}{|c|}{ Plant height (cm) } \\
\cline { 2 - 4 } & VD & FOL & FORL \\
\hline Salicylic acid & $46.8 \mathrm{a}$ & $53 \mathrm{a}$ & $44 \mathrm{a}$ \\
\hline Chitosan & $42.2 \mathrm{ab}$ & $50 \mathrm{ab}$ & $42.4 \mathrm{a}$ \\
\hline Inoculated control & $38.4 \mathrm{~b}$ & $40.8 \mathrm{~b}$ & $36.2 \mathrm{c}$ \\
\hline Uninoculated control & $44.4 \mathrm{ab}$ & $42.3 \mathrm{~b}$ & $40.2 \mathrm{ab}$ \\
\hline
\end{tabular}

*For each pathogen tested, values (means) followed by the same letter are not significantly different according to Duncan's Multiple Range test at $P \leq 0.05$.

Table 5: Effect of chitosan- and salicylic acid-based treatments on height of tomato cv. Rio Grande plants inoculated with Verticillium dahliae (VD), Fusarium oxysporum f. sp. lycopersici (FOL) and F. oxysporum f. sp. radicis-lycopersici (FORL) noted 60 days post-inoculation under growth chamber conditions. Chitosan $(4 \mathrm{mg} / \mathrm{ml})$ and SA (10 mM) were applied as soil drench five days before inoculation.

\begin{tabular}{|c|c|c|c|}
\hline \multirow{2}{*}{ Treatment/Pathogen } & \multicolumn{3}{|c|}{ Root fresh weight (g/plant) } \\
\cline { 2 - 4 } & VD & FOL & FORL \\
\hline Salicylic acid & $18.4 \mathrm{a}$ & $14.8 \mathrm{a}$ & $11.2 \mathrm{ab}$ \\
\hline Chitosan & $15.2 \mathrm{ab}$ & $11.2 \mathrm{ab}$ & $14.8 \mathrm{a}$ \\
\hline Inoculated control & $8.8 \mathrm{~b}$ & $6.6 \mathrm{~b}$ & $5.6 \mathrm{c}$ \\
\hline Uninoculated control & $14 \mathrm{ab}$ & $11.4 \mathrm{ab}$ & $8.8 \mathrm{bc}$ \\
\hline
\end{tabular}

*For each pathogen tested, values (means) followed by the same letter are not significantly different according to Duncan's Multiple Range test at $P \leq 0.05$.

Table 6: Effect of chitosan- and salicylic acid-based treatments on root fresh weight of tomato cv. Rio Grande plants inoculated with Verticillium dahliae (VD), Fusarium oxysporum f. sp. lycopersici (FOL) and F. oxysporum f. sp. radicis-lycopersici (FORL) noted 60 days post-inoculation under growth chamber conditions. Chitosan $(4 \mathrm{mg} / \mathrm{ml})$ and $\mathrm{SA}(10 \mathrm{mM})$ were applied as soil drench five days before inoculation.

\begin{tabular}{|c|c|c|c|}
\hline & \multicolumn{3}{|c|}{ Aerial part fresh weight (g) } \\
\hline Treatment/Pathogen & VD & FOL & FORL \\
\hline Salicylic acid & $73.8 \mathrm{a}$ & $81.4 \mathrm{a}$ & $76 \mathrm{a}$ \\
\hline Chitosan & $82 \mathrm{a}$ & $68.8 \mathrm{~b}$ & $66.2 \mathrm{a}$ \\
\hline Inoculated control & $49.2 \mathrm{~b}$ & $57.2 \mathrm{~b}$ & $40.4 \mathrm{~b}$ \\
\hline Uninoculated control & $72.2 \mathrm{a}$ & $66.2 \mathrm{~b}$ & $60.2 \mathrm{ab}$ \\
\hline
\end{tabular}

*For each pathogen tested, values (means) followed by the same letter are not significantly different according to Duncan's Multiple Range test at $P \leq 0.05$.

Table 7: Effect chitosan- and salicylic acid-based treatments on aerial part fresh weight of tomato cv. Rio Grande plants inoculated with Verticillium dahliae (VD), Fusarium oxysporum f. sp. lycopersici (FOL) and F. oxysporum f. sp. radicislycopersici (FORL) noted 60 days post-inoculation under growth chamber conditions Chitosan $(4 \mathrm{mg} / \mathrm{ml})$ and SA $(10 \mathrm{mM})$ were applied as soil drench five days before inoculation.

In comparison to FOL-inoculated plants, SA treatment had significantly improved root fresh weight by $55.40 \%$ and was statistically comparable to the untreated and uninoculated control. Chitosantreated plants showed significantly comparable root fresh weight to that noted on both untreated controls (FOL-inoculated or non) and also on SA-treated plants.

An increase of about $41.07 \%$ in root fresh weight, even statistically insignificant, was noted on chitosan-treated plants in comparison to the untreated and uninoculated control ones.

Chitosan-treated plants showed significantly enhanced root fresh weight by about 62.16 and $40.54 \%$, compared to FORL-inoculated and non-controls, respectively. Root fresh weight noted on SA-treated plants was improved by $50 \%$, which was significantly comparable to that of Chitosan-treated plants and that of the uninoculated control.

\section{Aerial part fresh weight}

Aerial part fresh weight, noted 60 DPI on tomato plants cv. Rio Grande, varied significantly (at $P \leq 0.05$ ) depending on treatments tested. In fact, aerial part fresh weights recorded on SA- and chitosantreated plants were statistically comparable and were increased by 33.33 and $40 \%$ compared to VD-inoculated plants and were also statistically similar to that of the uninoculated plants.

Exogenously applied SA-based treatment resulted in 29.72\% increase in plant's aerial part fresh weight in comparison to FOLinoculated and untreated control plants. Chitosan-treated plants showed aerial part fresh weight statistically comparable to that recorded on both FOL-inoculated or non-control plants; a slight increase of about $16.86 \%$ was noted compared to uninoculated control.

Aerial part fresh weight recorded on SA- and chitosan-treated plants was significantly increased by 46.84 and $38.97 \%$ compared to FORL-inoculated ones and was also statistically similar to uninoculated 
Citation: Jabnoun-Khiareddine H, El-Mohamedy RSR, Abdel-Kareem F, Aydi Ben Abdallah R, Gueddes-Chahed M, et al. (2015) Variation in Chitosan and Salicylic Acid Efficacy Towards Soil-borne and Air-borne Fungi and their Suppressive Effect of Tomato Wilt Severity. J Plant Pathol Microbiol 6: 325. doi:10.4172/2157-7471.1000325

plants. These treatments had also improved, even statistically insignificant, the aerial part fresh weight by 20.78 and $9 \%$ compared to the uninoculated control plants.

\section{Discussion}

In Tunisia, little attention has been paid to the antifungal activity of chitosan towards tomato pathogens. Indeed, the present study demonstrates that this natural compound applied at concentrations varying from 0.5 to $4 \mathrm{mg} / \mathrm{ml}$ is effective in inhibiting the radial growth of several fungi, i.e., F. oxysporum f. sp. lycopersici, F. oxysporum f. sp. radicis-lycopersici, F. solani, VD, C. coccodes, $R$. solani, $P$. aphanidermatum, S. sclerotiorum, B. cinerea and A. solani.

An increasing number of studies have been focused on the effect of chitosan on several phytopathogenic fungal species and its ability to reduce their in vitro growth [35-38]. In this regard, El Ghaouth, et al. [39] showed that chitosan used at $3.0 \mathrm{mg} / \mathrm{ml}$ reduced the radial growth of B. cinerea, Rhizopus stolonifer, A. alternata and C. gloeosporioides. Recently, Al-Najada and Gherbawy [40] found that four different concentrations of chitosan $(20,30,50$, and $100 \mathrm{mg} / \mathrm{l})$ led to highly significant decrease in the average radial growth of 22 species of spoilage fungi.

In the present study, we demonstrated that the percentage of fungal growth inhibition recorded in chitosan-amended PDA medium was dependent on concentrations used, and that the highest mycelial growth decrease was achieved using chitosan at $4 \mathrm{~g} / \mathrm{l}$. This result is on line with those reported in various studies where a dose-response relationship was generally observed for each tested fungus expressed as average fungal growth decrease with the increase of chitosan concentrations. In fact, El Ghaouth, et al. [39] demonstrated that chitosan reduced markedly the radial growth of $B$. cinerea, Rhizopus stolonifer, A. alternata and C. gloeosporioides with a greater effect at higher concentrations. Wade and Lamondia [41] also noted a linear decrease of $R$. solani growth with the gradual increase from 0.5 to 6.0 $\mathrm{mg} / \mathrm{ml}$ of chitosan concentration. Bell, et al. [42] mentioned that all isolates of F. oxysporum f. sp. apii were progressively and uniformly inhibited by concentrations of chitosan up to $3 \mathrm{mg} / \mathrm{ml}$. Trotel-Aziz, et al. [43] showed that the level of mycelial growth inhibition of $B$. cinerea is highly correlated with chitosan concentration. Liu, et al. [44] also found that inhibitory effects of chitosan against B. cinerea and Penicillium expansum varied significantly depending on chitosan concentrations. Badawy and Rabea [45] found that the radial growth of A. alternata, B. cinerea, C. gloeosporioides, and R. stolonifer decreased with the increase of chitosan concentration (750-6000 mg/l).

In the current study, interspecific variations in sensitivity to chitosan was apparent. In fact, applied at 2.5 and $3 \mathrm{mg} / \mathrm{ml}$, chitosanbased treatment led to complete inhibition of $P$. aphanidermatum and $S$. sclerotiorum growth, respectively, while at the highest concentration tested ( $4 \mathrm{~g} / \mathrm{l})$, F. solani and R. solani were inhibited by 47.71 and $54.58 \%$, respectively. Furthermore, using the same chitosan concentrations, significant differences were noted between Fusarium species. For instance, at $0.5 \mathrm{mg} / \mathrm{ml}$ chitosan, F. solani and FOL were inhibited by 2.29 and $24.79 \%$, respectively. Furthermore, at $2.5 \mathrm{mg} / \mathrm{ml}$ chitosan, F. solani and FORL were inhibited by 33.49 and $59.26 \%$, respectively. Our results are in agreement with several studies reporting variation in sensibility to chitosan between fungal species [39,46-48]. PalmaGuerrero, et al. [49] mentioned varied tolerance to chitosan between fungi and found that F. oxysporum f. sp. radicis-lycopersici, P. ultimum and $R$. solani were the most sensitive to chitosan. Xu, et al. [50] also found that VD was the most tolerant to chitosan among nine plant- pathogenic fungi exhibiting varied responses to chitosan-based treatments. Similar effect was reported by El Ghaouth, et al. [39] who showed that $R$. stolonifer was the least sensitive to chitosan compared to $B$. cinerea, A. alternata and C. gloeosporioides at the concentration of $3 \mathrm{mg} / \mathrm{ml}$. El-Ghaouth, et al. [46] reported that chitosan used at $400 \mathrm{mg} / \mathrm{l}$ totally inhibited $P$. aphanidermatum mycelial growth but total suppression of $F$. oxysporum, $R$. stolonifer, P. digitatum, and $C$. gloeosporioides was achieved using at $3 \%[47,48]$.

Variation in chitosan inhibitory effects was reported also between closely related microorganisms. In fact, when testing sensitivity of many fungal species to chitosan, Al-Najada and Gherbawy [40] found that $50 \mathrm{mg} / \mathrm{l}$ of chitosan completely inhibited growth of $A$. consortialis, Neofusicoccum parvum and many other fungi, while $100 \mathrm{mg} / \mathrm{l}$ of chitosan totally inhibited growth of A. tenuissima, Cladosporium cladosporioides, F. solani, Macrophomina phaseolina, R. solani, and others.

In the present study, $4 \mathrm{mg} / \mathrm{ml}$ chitosan was insufficient to completely inhibit $B$. cinerea mycelial growth which is not the case in many other studies. In fact, El-Ghaouth, et al. [39] explained that differences in results could originate from differences in methods used for incorporation of chitosan into growth medium. Guerra-Sánchez, et al. [51] also mentioned that the culture medium may influence on the inhibitory effects of the chitosan as some of them allow measuring the released compounds after chitosan addition without interference.

Moreover, Song, et al. [52] found that toxicity induced by chitosan was dependent on concentration, molecular weight, degree of acetylation, solvent, $\mathrm{pH}$ and viscosity.

Many explanations have been postulated for the mode of action of chitosan against fungi $[21,39,53,54]$. In fact, the polycationic nature of this compound is considered a key to its antifungal properties and the length of the polymer chain enhances its antifungal activity (Hirano and Nagao, 1989). Chitosan also induces marked morphological changes and structural alterations of the fungal cells [21,39,54].

In the current study, SA inhibited hyphal growth of the phytopathogenic fungi tested in a dose dependant manner. These results are consistent with many known reports. Indeed, similar effect was reported in [31] study where a significant negative correlation was detected between SA concentration and F. oxysporum f. s. ciceri Rs1 mycelial growth in a Petri-plate assay. These authors found that using SA at $100 \mu \mathrm{g} / \mathrm{ml}$, no inhibition was observed but at $2000 \mu \mathrm{g} / \mathrm{ml}$, pathogen mycelial growth was completely stopped. In the same sense, Abdel-Monaim, et al. [55] showed that SA tested at 50, 100 and 200 ppm had significantly inhibited radial growth, mycelial dry weight and spore formation of $F$. oxysporum $\mathrm{f}$. sp. lycopersici but at different degrees depending on concentrations tested.

$\mathrm{Wu}$, et al. [56] found that this RI decreased hyphal growth and biomass of F. oxysporum f. sp. niveum where the dry weight of mycelia, noted using the highest concentration $(800 \mathrm{mg} / \mathrm{l})$, showed $52 \%$ decrease in liquid culture. The obtained result was also in agreement with [57] where SA used at $270 \mathrm{mg} / \mathrm{l}$ exhibited fungitoxicity toward Monilinia fructicola and significantly inhibited it's in vitro growth.

The present finding was in accordance with those of Amborabé, et al. [58] reporting that SA inhibitory activity toward Eutypa lata, noted in solid and liquid culture media, also varied in a concentrationdependent manner with the threshold concentration being fixed at 13.8 $\mathrm{mg} / \mathrm{l}$. Amborabé, et al. [58] also reported that the antifungal efficiency of SA was higher when the experimental $\mathrm{pH}$ was brought to more acidic values ( $\mathrm{pH} 4)$. 
Citation: Jabnoun-Khiareddine H, El-Mohamedy RSR, Abdel-Kareem F, Aydi Ben Abdallah R, Gueddes-Chahed M, et al. (2015) Variation in Chitosan and Salicylic Acid Efficacy Towards Soil-borne and Air-borne Fungi and their Suppressive Effect of Tomato Wilt Severity. J Plant Pathol Microbiol 6: 325. doi:10.4172/2157-7471.1000325

In the present study, SA used at $1 \mathrm{mM}$ caused only 19 and $23 \%$ decrease in FOL and FORL mycelial growth, respectively. This is in line with $[26,59]$ results where the three SA concentrations tested $(100 \mu \mathrm{M}, 200 \mu \mathrm{M}$ and $300 \mu \mathrm{M})$ had significantly inhibited FOL and FORL growth compared to the control. Similar effects were reported for other pathogens such as R. stolonifer, F. oxysporum, R. solani, S. rolfsii, $M$. phaseolinae, Pythium sp., and Phytophthora using SA at a minimum concentration of $2.5 \mathrm{mM}[60,61]$. Also, da Rocha Neto, et al. [62] found that SA was able to completely suppress germination of $P$. expansum conidia at $2.5 \mathrm{mM}$ and that this compound caused leakage of the pathogen's proteins to the medium, measurable lipid damage, and intracellular disorganization.

To our knowledge, this is the first report on the in vitro antifungal activity of chitosan and salicylic acid against major fungal pathogens infecting tomato in Tunisia.

In the present study, SA and chitosan were tested as soil drench 5 days before tomato plants were challenged with three soil-borne pathogens. In fact, different application methods have been used for the chemical induction of systemic resistance in plants. For example, Thulke and Conrath [63] showed that SA applied either as a seed treatment, spray or soil drench induced systemic resistance in cacao against Phytophthora palmivora. Furthermore, for tomato, the period between application of the inducer and the effective activation of defence responses were observed within a short period, 3-7 days postinoculation [64,65]. In the same sense, Guzmán-Téllez, et al. [66] reported that SA applications on tomato should be performed within a minimum interval of eight days in order to maintain SA concentration related with the increase in plant tolerance to environmental stress.

Interesting results from our in vitro essays were also confirmed by the in vivo experiments where single treatments with chitosan and SA resulted in varied degree of protection against Verticillium wilt, Fusarium wilt and Fusarium Crown and Root Rot. In fact, chitosanbased treatment resulted in $73.68,60.86$, and $45 \%$ reductions in wilt severity, as respectively compared to VD-, FOL- and FORL-inoculated and untreated controls. The protective effect of chitosan against severe tomato wilt pathogens has been reported in numerous investigations on a range of crops where the antifungal activity of chitosan has been proven both in vitro and in vivo [21]. [67] also reported that chitosan used to control plant pathogens has been extensively explored with more or less success depending on pathosystems, used derivatives, concentrations, degree of deacetylation, viscosity, and applied formulation (i.e., soil amendment, foliar application, chitosan alone or in association with other treatments). Chitosan has also been extensively utilized as a seed treatment and as soil amendment to control $F$. oxysporum in many host plants [68]. In fact, applied at an optimal concentration, this biomaterial is able to induce a delay in disease development leading to reduced plant wilting [69]. For example, chitosan was shown to protect tomato plants from Fusarium crown and root rot [69] when used as seed treatment and from Fusarium wilt when applied as foliar spray [64]. In soilless tomato, Benhamou and Lafontaine [70] reported that root rot caused by F. oxysporum f. sp. radicis-lycopersici was suppressed using chitosan-based amendments.

Studies of Cretoiu, et al. [71] demonstrated that amendment of chitin, which is a precursor of chitosan, improved soil suppressiveness to VD. Recently, Amini [72] also found that chitosan affected VD growth in vitro and reduced disease severity and significantly increased weight of potato tubers under greenhouse conditions. In fact, chitosan is often used for plant disease control as a powerful elicitor. When applied to plant tissues, chitosan often agglutinates around penetration sites and forms a physical barrier preventing pathogen from spreading and invading other healthy tissues and it is able to bind various materials and initiate fast wound healing process. Chitosan and derivatives are known to act as potent inducers, enhancing a battery of plant responses both locally around the infection sites and systemically to alert healthy parts of the plant. These include early signaling events as well as the accumulation of defence-related metabolites and proteins such as phytoalexins and PR-proteins $[44,45,67,73]$.

The results of the current study are also in concordance with others studies showing that chitosan has a double effect: it acts as antimicrobial abiotic agent and it also activates several plant defense mechanisms during host-pathogen interactions. These combined effects led to reduced disease severity due to callose deposition, lignification, synthesis of abscisic acid, phytoalexins, and pathogenesisrelated proteins as reported in previous studies $[21,74]$.

The present study highlights the protective effect of SA against the economically important fungal diseases. In fact, exogenous application of SA $(10 \mathrm{mM})$ as soil drench had reduced by $42.1,78.26$ and $50 \%$ wilt severity, as respectively compared to VD-, FOL- and FORL-inoculated and untreated controls. Similar results were reported in Mandal, et al. [59] study where exogenous application of SA at $200 \mathrm{mM}$, through root feeding and foliar spray, led to reduced vascular browning and leaf yellowing caused by FOL on tomato plants. In fact, SA-treated plants already challenged with FOL exhibited increased levels of peroxidases and phenylalanine ammonia-lyase activities and also endogenous accumulation of free SA, showing that the root system might assimilate and distribute SA throughout the plant and ultimately activate systemic disease resistance [59,75]. In this regard, AbdelMonaim [76] reported that SA protected tomato plants from Fusarium wilt disease and induced resistance with increased concentrations. Ojha and Chatterjee [77] also indicated that soil application of SA following inoculation with FOL resulted in maximum peroxidase and polyphenol oxidase activity in tomato leaves on the $28^{\text {th }}$ day which might play an important role in plant resistance and defense system activation. In fact, it has been shown that exogenous SA treatment prior to inoculation provided increased $F$. oxysporum resistance as evidenced by reduced foliar necrosis and plant death in Arabidopsis [78]. Furthermore, exogenous SA stimulated the systemic resistance and significantly reduced Fusarium wilt severity in chickpea [31]. In the same sense, pre-treatment of asparagus roots with SA primed plants for a potentiated defence response toward F. oxysporum $\mathrm{f}$. $\mathrm{sp}$. asparagi associated with increased levels of peroxidases, phenylalanine ammonia-lyase and lignifications [79]. External application of SA to Arabidopsis and tobacco boosts endogenous SA signal production, and induces systemic acquired resistance responses against pathogens including expression of the pathogenesis related genes that are implicated in disease resistance [80-82].

Recently Jendoubi, et al. [26] found that SA, applied at $200 \mu \mathrm{M}$ directly to the root system, had activated systemically resistance against FORL in hydroponically grown tomato plants. In the same sense, [83] demonstrated the induced resistance to VD toxin in cotton achieved using exogenous SA which was coupled with an increased in $\beta$-1,3-glucanase production while cellular integrity was maintained and damage to cell wall and plasma membrane was avoided. These results are also in line with those of [84] who showed that chickpea seed treatment with SA reduced Fusarium wilt disease by $40 \%$. In this regards, [27] mentioned that in field trials, treatment of tomato plants with SA at $100 \mathrm{mM}$ resulted in reduction of root rot incidence and disease severity caused by F. solani, R. solani and S. rolfsii. [85] found 
Citation: Jabnoun-Khiareddine H, El-Mohamedy RSR, Abdel-Kareem F, Aydi Ben Abdallah R, Gueddes-Chahed M, et al. (2015) Variation in Chitosan and Salicylic Acid Efficacy Towards Soil-borne and Air-borne Fungi and their Suppressive Effect of Tomato Wilt Severity. J Plant Pathol Microbiol 6: 325. doi:10.4172/2157-7471.1000325

that tomato plants sprayed with SA, as inducer, for $48 \mathrm{~h}$ before root inoculation with FOL provided induced resistance in plant against this pathogen and resulted in disease incidence decline, 15 days post inoculation

In the present study, tomato plants treated with $10 \mathrm{mM} \mathrm{SA}$ and 4 $\mathrm{mg} / \mathrm{ml}$ chitosan enhanced all tomato growth parameters tested (height, aerial part and root fresh weights) compared to pathogen-inoculated control. In fact, SA-based-treatment had significantly increased plant height, root and aerial part fresh weights by $17.94,52.17$ and $33.33 \%$, by $23.01,55.40 \%$ and $29.72 \%$, and by $17.72,50$ and $46.84 \%$, respectively, while compared to VD-, FOL- and FORL-inoculated and untreated plants. Furthermore, a significant improve, by $20.18 \%$, in plant height was also recorded in SA- treated and VD-inoculated plants compared to uninoculated and untreated control. In fact, growth-stimulating effects of SA have been reported in many plants such as soybean, wheat, maize, and chamomile [86]. Furthermore, Abo-Hamed, et al. [87] reported that soil drench with salicylate led to an increase in the fresh and dry weight of shoot and at lower concentration appeared to enhance plant height and leaf area of wheat plant. Rivas-San, et al. [86] mentioned that the effect of exogenous SA supply on growth depends on plant species, developmental stage, and SA concentrations tested. In the same sense, [27] have also reported that the application of SA was among the most efficient RIs tested for increase of growth parameters (plant height and number of branches), yield and quality of tomato fruits under field conditions during two cropping seasons. Abd ElGawad and Bondok [88] found that foliar application of SA $(2 \mathrm{mM} / \mathrm{l})$ and chitosan $(0.1 \%)$ significantly improves tomato vegetative growth.

In the current study, the growth-stimulating effect of chitosan was observed mainly on FORL-inoculated plants. In fact, a significant improve of tomato height by $13.81 \%$ was noted on chitosan-treated plants, compared to FORL-inoculated and untreated control ones. Furthermore, an enhanced root fresh weight by about 62.16 and $40.54 \%$ was also recorded, compared to FORL-inoculated and non-controls. The aerial part fresh weight recorded on chitosan-treated plants was significantly increased by 38.97 and $40 \%$ compared to FORL- and VDinoculated plants, respectively. The positive effect of chitosan on the growth of roots, shoots and leaves of various plants have been previously reported [89-91]. In fact, Algam, et al. [92] reported that chitosan had successfully controlled Ralstonia wilt in tomato as well as promoted tomato growth. El-Mougy, et al. [93] also demonstrated that tomato root rot pathogens were successfully controlled using chitosan, and recorded $66.7 \%$ increased yield using this compound. Abdel-Mawgoud, et al. [90] indicated that chitosan application improved strawberry plant height, number of leaves, fresh and dry weights of the leaves and yield components. Also, Sheikha and Al-Malki [91] indicated that chitosan works as a positive factor in enhancing bean shoot and root length, fresh and dry weights of shoots and roots as well as leaves area. In this regard, Farouk [89] mentioned that a positive effect of chitosan was observed on the growth of roots, shoots and leaves of various plants including cucumber. In the same sense, El-Tantawy [94] found that spraying tomato plants with chitosan increased all vegetative growth parameters expressed in plant height, number of branches, number of leaves and plant fresh and dry weight. Recently, Algam and Elwagia [95] found that tomato growth parameters were significantly increased using chitosan-based treatments compared to control. In fact, the application of chitosan at $5 \mathrm{mg} / \mathrm{ml}$ as foliar spray combined with 5 $\mathrm{mg} / \mathrm{ml}$ as seed treatment had increased plant height and fresh and dry weight by $16,36,24 \%$, respectively.

\section{Conclusion}

In this study, it was observed that RIs tested possess variable antifungal activity in vitro depending on fungal tomato pathogens tested and concentrations used. They were shown to have direct antifungal potential and also indirect effect through by decreasing tomato wilt incited by FOL, FORL and VD and by enhancing growth. Based on these findingss, it could be concluded that, when applied as soil drench, chitosan used at $4 \mathrm{mg} / \mathrm{ml}$ and SA applied at $10 \mathrm{Mm}$ may markedly suppress Verticillium wilt, Fusarium wilt, and Fusarium Crown and Root Rot severities and enhance tomato plant growth Thus, SA and chitosan may be used as potential inducer of systemic acquired resistance against the devastating soil-borne vascular wilt pathogens of tomato. Further studies are needed to more elucidate the exact mechanism deployed by these inducers via different modes and timings of application. The current study indicates that inducing plant's own defense mechanisms using these RIs can be integrated in plant disease management together with other control environmentally safe alternatives such as biocontrol, grafting, and solarisation.

\section{Acknowledgement}

This work was carried out during a Collaborative Project between Tunisia and Egypt, titled Integrated management for controlling tomato fungal diseases unde Egyptian and Tunisian conditions, funded by the Ministry of Scientific Research, in Egypt (Grand no.4/10/4) and the Ministry of Higher Education and Scientific Research of Tunisia.

\section{References}

1. Olaniyi JO, Akanbi WB, Adejumo TA, Akande OG (2010) Growth, fruit yield and nutritional quality of tomato varieties. Afr J Food Sci 4: 398-402.

2. Rakha M, Scott J, Hutton S, Smith H (2011) Identification of trichomes, loci and chemical compounds derived from Solanum habrochaites accession LA1777 that are associated with resistance to the sweet potato whitefly, Bemisia tabaci in tomato, S. lycopersicum. 43rd Tomato Breeders Meeting. University of Florida.

3. Ananymous (2015) Groupement Interprofessionnel des légumes, filières des legumes.

4. Gajanana TM, Krishna Moorthy PN, Anupama HL, Raghunatha R, Kuma GTP (2006) Integrated pest and disease management in tomato: an economic analysis. Agric Econ Res Rev 19: 269-280.

5. Hibar K, Daami-Remadi M, El-Mahjoub M (2007) Induction of resistance in tomato plants against Fusarium oysporum f. sp. radicis-lycopersici by Trichoderma spp. Tunisian J Plant Prot 2: 47-58

6. Jabnoun-Khiareddine $\mathrm{H}$, Daami-Remadi M, Ayed F, El Mahjoub M (2009) Biocontrol of tomato Verticillium wilt by using indigenous Gliocladium spp. and Penicillium sp. isolates. Dynamic Soil Dynamic Plant 3: 70-79.

7. Jabnoun-Khiareddine H, Daami-Remadi M, Platt HW, Ayed F, El Mahjoub M (2010) Variation in aggressiveness of Tunisian Verticillium dahliae races 1 and 2 isolates and response of differential tomato cultivars to Verticillium wilt. International Journal of Plant Breeding 4: 63-70.

8. Hassine $M$, Aydi-Ben Abdallah $R$, Jabnoun-Khiareddine $H$, Ben Jannet $H$ Daami-Remadi M (2013) Effet des températures d'incubation et des méthodes de confrontation sur le pouvoir inhibiteur exercé par Penicillium sp. et Gliocladium spp. sur Botrytis cinerea. Tunis J Med Plants Nat Prod 9: 41-51.

9. Hassine M, Aydi-Ben Abdallah R, Jabnoun-Khiareddine H, Daami-Remadi M (2014) Pouvoir antifongique des Penicillium sp. et des Gliocladium spp. Contre Alternaria solani in vitro et sur fruits de tomate. Tunis $\mathrm{J}$ Med Plants Nat Prod 12: 9-28.

10. Batish DR, Singh HP, Kohli RK, Kaur S (2008) Eucalyptus essential oil as a natural pesticide. For Ecol Manage 256: 2166-2174.

11. Nicholls Cl, Altieri MA (2013) Plant biodiversity enhances bees and other insect pollinators in agroecosystems. Agron Sustain Dev 33: 257-274.

12. Kamble A, Koopmann B, von Tiedemann A (2013) Induced resistance to Verticillium longisporum in Brassica napus by b-aminobutyric acid. Plant Patho 62: 552-561. 
Citation: Jabnoun-Khiareddine H, El-Mohamedy RSR, Abdel-Kareem F, Aydi Ben Abdallah R, Gueddes-Chahed M, et al. (2015) Variation in Chitosan and Salicylic Acid Efficacy Towards Soil-borne and Air-borne Fungi and their Suppressive Effect of Tomato Wilt Severity. J Plant Pathol Microbiol 6: 325. doi:10.4172/2157-7471.1000325

13. Kessmann H, Staub T, Hofmann C, Maetzke T, Herzog J, et al. (1994) Induction of systemic acquired disease resistance in plants by chemicals. Annu Rev Phytopathol 32: 439-459.

14. Kuc $J$ (2001) Concepts and direction of induced systemic resistance in plants and its application. Eur J Plant Pathol 107: 7-12.

15. Edreva A (2004) A novel strategy for plant protection: Induced resistance. $J$ Cell Mol Biol 3: 61-69.

16. Lyon GD, Reglinski T, Newton AC (1995) Novel disease control compounds: the potential to 'immunize' plants against infection. Plant Pathol 44: 407-427.

17. Schneider M, Schweizer P, Meuwly P, Métraux JP (1996) Systemic acquired resistance in plants. Int. Rev. Cytology 168: 303-340.

18. Benhamou N, Picard K (1999) La résistance induite: une nouvelle stratégie de défense des plantes contre les agents pathogènes. Phytoprotection 80: 137 168.

19. Cohen Y (2001) The BABA story of induced resistance. Phytoparasitica 29 : $375-378$.

20. Benhamou N (1996) Elicitor-induced plant defence pathways. Trends Plant Sc 1: $233-240$.

21. Bautista-Baños S, Hernández-Lauzardo AN, Velázquez-del Valle MG Hernández-López M, Ait Barkab E, et al. (2006) Chitosan as a potential natural compound to control pre and postharvest diseases of horticultural commodities. Crop Prot 25: 108-118.

22. Bhattacharya A (2013) Fungicidal potential of chitosan against phytopathogenic Fusarium Solani. J Exp Biol \& Agr Sci 1: 259-263.

23. Hammerschmidt R, Smith-Becker JA (2000) The role of salicylic acid in disease resistance in mechanisms of resistance to plant diseases. Eds: Slusarenko A Fraser RSS, Van Loon LC, Kluwer Academic Publisher.

24. Zgnen H, Mehmet B, Erkili A (2001) The Effect of salicylic acid and endomycorrhizal fungus Glomus etunicatum on plant development of tomatoes and Fusarium wilt caused by Fusarium oxysporum f. sp lycopersici. Turk J Agric 25: 25-29.

25. El-Khallal SM (2007) Induction and modulation of resistance in tomato plants against Fusarium wilt disease by bioagent fungi (arbuscular mycorrhiza) and/ or hormonal elicitors (jasmonic acid and salicylic acid): 1- changes in growth, some metabolic activities and endogenous hormones related to defence mechanism. Australian J Basic Appl Sci 1: 691-705.

26. Jendoubi W, Harbaoui K, Hamada W (2015) Salicylic acid-induced resistance against Fusarium oxysporum f.s.p radicis-lycopercisi in hydroponic grown tomato plants. Journal of New Sciences 21: 985-995.

27. El-Mohamedy RSR, Jabnoun-Khiareddine H, Daami-Remadi M (2014) Contro of root rot diseases of tomato plants caused by Fusarium solani, Rhizoctonia solani and Sclerotium rolfsii using different chemical plant resistance inducers. Tunisian J Plant Prot 9: 45-55.

28. Abdou ES, Abd-Alla HM, Galal AA (2001) Survey of sesame root rot/wilt disease in Minia and their possible control by ascorbic and salicylic acids. Assuit J of Agric Sci 32: 135-152.

29. Mahesh HM, Sharada MS (2014) Role of salicylic acid in induction of resistance in Brinjal (Solanum melongena L.) against Verticillium dahliae. Int J Recent Sci Res 5: 1865-1870.

30. He CY, Wolyn DJ (2005) Potential role for salicylic acid in induced resistance of asparagus roots to Fusarium oxysporum f.sp. asparagi. Plant Pathol 54: 227232.

31. Saikia S, Singh T, Kumar R, Srivastava J, Srivastava AK, et al. (2003) Role of salicylic acid in systemic resistance induced by Pseudomonas fluorescens against Fusarium oxysporum f. sp. ciceri in chickpea. Microbiol Res 158: 203213.

32. Pharand B, Carisse O, Benhamou N (2002) Cytological aspects of compostmediated induced resistance against fusarium crown and root rot in tomato. Phytopathology 92: 424-438.

33. El Ghaouth A, Arul J, Ponnampalam R (1991) Use of chitosan coating to reduce water loss and maintain quality of cucumbers and bell pepper fruits. $J$ Food Process Preservation 15: 359-368.

34. Tiru M, Muleta D, Bercha G, Adugna G (2013) Antagonistic effect of rhizobacteria against coffee wilt disease caused by Gibberella xylarioides. Asian J Plant Pathol 7: 109-122.
35. Romanazzi G, Nigro F, Ippolito A (2001) Chitosan in the control of postharvest decay of some Mediterranean fruits. In: Muzarelli, R.A.A. (Ed.), Chitin Enzymology, Atec, Italy.

36. El Ghaouth A, Arul J, Wilson C, Benhamou N (1997) Biochemical and cytochemical aspects of the interactions of chitosan and Botrytis cinerea in bell pepper fruit. Postharvest Biol Technol 12: 183-194.

37. Bhaskara Reddy MV, Arul J, Angers P, Couture L (1999) Chitosan treatment of wheat seeds induces resistance to Fusarium graminearum and improves seed quality. J Agric Food Chem 47: 1208-1216.

38. Rhoades J, Roller S (2000) Antimicrobial actions of degraded and native chitosan against spoilage organisms in laboratory media and foods. App Environ Microbiol 66: 80-86.

39. El Ghaouth A, Ponnampalam R, Castaigne F, Arul J (1992) Chitosan coating to extend the storage life of tomatoes. HortScience 27: 1016-1018.

40. Al-Najada AR, Gherbawy YA (2015) Molecular identification of spoilage fungi isolated from fruit and vegetables and their control with chitosan. Food Biotechnol 29: 166-184.

41. Wade HE, Lamondia JA (1994) Chitosan inhibits Rhizoctonia fragariae but not strawberry black root rot. Adv Strawberry Res 13: 26-31.

2. Bell AA, Hubbard JC, Liu L, Davis RM, Subbarao KV (1998) Effects of chitin and chitosan on the incidence and severity of Fusarium yellows in celery. Plant Dis 82: $322-328$.

43. Trotel-Aziz P Couderchet M, Vernet G, Aziz A (2006) Chitosan stimulates defense reactions in grapevine leaves and inhibits development of Botrytis cinerea. Eur J plant pathol 114: 405-13.

44. Liu J, Tian S, Meng X, Xu Y (2007) Effects of chitosan on control of postharvest diseases and physiological responses of tomato fruit. Postharvest Biol Technol 44: 300-306

45. Badawy MEI, Rabea El (2011) A biopolymer chitosan and its derivatives as promising antimicrobial agents against plant pathogens and their applications in crop protection. Int J Carbohyd Chem.

46. El-Ghaouth A, Arul J, Grenier J, Benhamou N, Asselin A, et al. (1994) Effect of chitosan on cucumber plants: suppression of Pythium aphanidermatum and induction of defence reactions. Phytopathology 84: 313-20.

47. Bautista-Baños $S$, Hernández-López $M$, Bosquez-Molina $E$, Wilson $C L$ (2003) Effects of chitosan and plant extracts on growth of Colletotrichum gloeosporioides, anthracnose levels and quality of papaya fruit. Crop Prot 22: 1087-1092.

48. Bautista-Baños S, Hernández-López M, Bosquez-Molina E (2004) Growth inhibition of selected fungi by chitosan and plant extracts. Mexican Journal of Phytopathology 22: 178-186.

49. Palma-Guerrero J, Jansson HB, Salinas J, Lopez-Llorca LV (2008) Effect of chitosan on hyphal growth and spore germination of plant pathogenic and biocontrol fungi. J Appl Microbiol 104: 541-553.

50. Xu J, Zhao X, Han X, Du Y (2007) Antifungal activity of oligochitosan against Phytophtora capsici and other pathogenic fungi in vitro. Pest Biochem Physio 87: 220-228

51. Guerra-Sánchez MG, Vega-Pérez J, Velázquez-del Valle MG, HernándezLauzardo AN (2009) Antifungal activity and release of compounds on Rhizopus stolonifer (Ehrenb.:Fr.) Vuill. by effect of chitosan with different molecular weights. Pesti Biochem Physiol 93: 18-22.

52. Song Y, Babiker EE, Usui M, Saito A, Kato A (2002) Emulsifying properties and bactericidal action of chitosan-lysozyme conjugates. Food Res Int 35: 459-466.

53. Hirano S, Nagao N (1989) Effect of chitosan, pectic acid, lysozyme and chitinase on growth of several phytopathogens. Agric Biol Chem 53: 3065-3066.

54. Ait Barka E, Eullaffroy P, Clément C, Vernet G (2004) Chitosan improves development, and protects Vitis vinifera L. against Botrytis cinerea. Plant Cell Rep 22: 608-614.

55. Abdel-Monaim MF, Abdel-Gaid MAW, Armanious HAH (2012) Effect of chemical inducers on root rot and wilt diseases, yield and quality of tomato. Int J Agr Sci 2: 210-220.

56. Wu HS, Raza W, Fan JQ, Sun YG, Bao W, et al. (2008) Antibiotic effect of exogenously applied salicylic acid on in vitro soilborne pathogen, Fusarium oxysporum f.sp.niveum. Chemosphere 74: 45-50. 
Citation: Jabnoun-Khiareddine H, El-Mohamedy RSR, Abdel-Kareem F, Aydi Ben Abdallah R, Gueddes-Chahed M, et al. (2015) Variation in Chitosan and Salicylic Acid Efficacy Towards Soil-borne and Air-borne Fungi and their Suppressive Effect of Tomato Wilt Severity. J Plant Pathol Microbiol 6: 325. doi:10.4172/2157-7471.1000325

57. Yao HJ, Tian SP (2005) Effects of pre- and post-harvest application of salicylic acid or methyl jasmonate on inducing disease resistance of sweet cherry fruit in storage. Posthar Biol Tech 35: 253-262.

58. Amborabé BE, Fleurat-Lessard P, Chollet JF, Roblin G (2002) Antifungal effects of salicylic acid and other benzoic acid derivatives towards Eutypa lata: structure-activity relationship. Plant Physiol Biochem 40: 1051-1060.

59. Mandal S, Mallick N, Mitra A (2009) Salicylic acid-induced resistance to Fusarium oxysporum f. sp. lycopersici in tomato. Plant Physiol Biochem 47: 642-649.

60. Panahirad S, Zaare-Nahandi F, Safaralizadeh R, Alizadeh-Salteh S (2012) Postharvest control of Rhizopus stolonifer in peach (Prunus persica L. Batsch) fruits using salicylic acid. J of Food Safety 32: 502-507.

61. El-Mohamedy SR, Abdel-Kader MM, Abd-El-Kareem F, El-Mougy NS (2013) Essential oils, inorganic acids and potassium salts as control measures against the growth of tomato root rot pathogens in vitro. International Journal of Agricultural Technology 9: 1507-1520

62. da Rocha Neto AC, Maraschin M, Di Piero RM (2015) Antifungal activity of salicylic acid against Penicillium expansum and its possible mechanisms of action. Int J Food Microbiol 215: 64-70.

63. Thulke O, Conrath $\cup(1998)$ Salicylic acid has a dual role in the activation of defence-related genes in parsley. Plant J 14: 35-42.

64. Benhamou N, Belanger RR (1998) Benzothiadiazole-mediated induced resistance to fusarium oxysporum $\mathrm{f}$. $\mathrm{sp}$. radicis-lycopersici in tomato Plant Physiol 118: 1203-1212.

65. Benhamou N, Bélanger RR (1998) Induction of systemic resistance to Pythium damping-off in cucumber plants by benzothiadiazole: ultrastructure and cytochemistry of the host response. Plant J 14: 13-21.

66. Guzmán-Téllez E, Montenegro DD, Benavides-Mendoza A (2014) Concentration of salicylic acid in tomato leaves after foliar aspersions of this compound. Am J Plant Sci 5: 2048-2056.

67. El Hadrami A, Adam LR, El Hadrami I, Daayf F (2010) Chitosan in plan protection. Mar Drugs 8: 968-987.

68. Rabea El, Badawy ME, Stevens CV, Smagghe G, Steurbaut W (2003) Chitosan as antimicrobial agent: applications and mode of action. Biomacromolecules 4 1457-1465.

69. Benhamou N, Kloepper JW, Tuzun S (1994) Induction of systemic resistance to Fusarium crown rot and root rot in tomato plants by seed treatment with chitosan. Phytopathology 84: 1432-1444.

70. Benhamou N, Lafontaine PJ (1994) Ultrastructural and cytochemical characterization of elicitor-induced structural responses in tomato root tissues infected by Fusarium oxysporum f. sp. radicis-lycopersici. Planta 197: 89-102.

71. Cretoiu MS, Korthals GW, Visser JHM, Elsas JD (2013) Chitin Amendment Increases Soil Suppressiveness toward Plant Pathogens and Modulates the Actinobacterial and Oxalobacteraceal Communities in an Experimental Agricultural Field. Appl Environ Microbiol 79: 5291-5301.

72. Amini $J(2015)$ Induced resistance in potato plants against Verticillium wilt invoked by chitosan and Acibenzolar-S-methyl. Aust J Crop Sci 9: 570-576.

73. El Ghaouth A, Smilanick JL, Wilson CL (2000) Enhancement of the performance of Candida saitoana by the addition of glycolchitosan for the control of postharvest decay of apple and citrus fruit. Postharvest Biol Technol 19: 103-110.

74. Cavalcanti FR, Resende MLV, Carvalho CPS, Silveira JAG, Oliveira JTA (2007) An aqueous suspension of Crinipellis perniciosa mycelium activates tomato defence responses against Xanthomonas vesicatoria. Crop Prot 26: 729-738.

75. Spletzer ME, Enyedi AJ (1999) Salicylic Acid Induces Resistance to Alternaria solani in Hydroponically Grown Tomato. Phytopathology 89: 722-727.

76. Abdel-Monaim MF (2012) Induced Systemic Resistance in Tomato Plants
Against Fusarium Wilt Disease. International Research Journal of Microbiology 3: $14-23$.

77. Ojha S, Chatterjee NC (2012) Induction of resistance in tomato plants against Fusarium oxysporum f. sp. lycopersici mediated through salicylic acid and Trichoderma harzianum. J Plant Prot Res 52: 220-225.

78. Edgar Cl, McGrath KC, Dombrecht B, Manners JM, Maclean DC, et al. (2006) Salicylic acid mediates resistance to the vascular wilt pathogen Fusarium oxysporum in the model host Arabidopsis thaliana. Aust Plant Pathol 35: 581 591.

79. He YL, Liu YL, Chen Q, Bian AH (2002) Thermotolerance related to antioxidation induced by salicylic acid and heat hardening in tall fescue seedlings. J Plant Physiol Mol 28: 89-95.

80. Delaney TP, Uknes S, Vernooij B, Friedrich L, Weymann K, et al. (1994) A central role of salicylic Acid in plant disease resistance. Science 266: 1247 1250 .

81. Summermatter K, Sticher L, Metraux JP (1995) Systemic Responses in Arabidopsis thaliana Infected and Challenged with Pseudomonas syringae pv syringae. Plant Physiol 108: 1379-1385.

82. Métraux JP, Nawrath C, Genoud T (2002) Systemic acquired resistance. Euphytica 124: 237-243.

83. Zhen XH, Li YZ (2004) Ultrastructural changes and location of ß-1,3-glucanase in resistant and susceptible cotton callus cells in response to treatment with toxin of Verticillium dahliae and salicylic acid. J Plant Physiol 161: 1367-1377.

84. Sarwar N, Zahid MHC, Haq I (2010) Seed treatments induced systemic resistance in chickpea against Fusarium wilt in wilt sick field. Pak J Bot 42 3323-3326.

85. Biswas SK, Pandey NK, Mohd R (2012) Inductions of defense response in tomato against Fusarium wilt through inorganic chemicals as inducers. J Plant Pathol Microb 3: 1-7.

86. Rivas-San Vicente M, Plasencia J (2011) Salicylic acid beyond defence: its role in plant growth and development. J Exp Bot 62: 3321-3338.

87. Abo-Hamed SA, Mansour FA, Aldesuquy HS (1987) Shoot growth and morphological characteristics of wheat as influenced by sodium salicylate, alar, asulam and kinetin. Mansoura Sci Bull 14: 203-221.

88. Abd El-Gawad HG, Bondok AM (2015) Response of Tomato Plants to Salicylic Acid and Chitosan under Infection with Tomato mosaic virus. AmericanEurasian J Agric \& Environ Sci 15: 1520-1529.

89. Farouk S, Ghoneem KM, Ali AA (2008) Induction and expression of systematic resistance to downy mildew disease in cucumber plant by elicitors. Egypt $J$ Phytopathol 36: 95-111.

90. Abdel-Mawgoud AM, Tantawy AS, El-Nemr MA, Sassine YN (2010) Growth and yield responses of strawberry plants to chitosan application. Eur J Sci Res 39: 161-168.

91. Sheikha SA, Al-Malki FM (2011) Growth and chlorophyll responses of bean plants to chitosan applications. Eur J Sci Res 50: 124-134.

92. Algam SAE, Xie GL, Li B, Yu SH, Su T, et al. (2010) Effects of Paenibacillus strains and chitosan on plant growth promotion and control of Ralstonia wilt in tomato. J Plant Pathol 92: 593-600.

93. El-Mougy NS, El-Gamal NG, Fotouh YO, Abd-El-Kareem F (2006) Tomato roo rot disease under greenhouse and field conditions. Res J Agric and Biol Sci 2 190-195.

94. El-Tantawy EM (2009) Behavior of tomato plants as affected by spraying with chitosan and aminofort as natural stimulator substances under application of soil organic amendments. Pak J Biol Sci 12: 1164-1173.

95. Algam SAE, Elwagia MEA (2015) Evaluation of chitosan efficacy on tomato growth and control of early blight disease. Jordan Journal of Agricultural Sciences 11: 27-36. 